\title{
Aid, Trade, and Agriculture
}

\author{
Michael R. Pakko
}

$\mathrm{T}$

he current round of multilateral trade negotiations among members of the World Trade Organization (WTO) launched in Doha, Qatar, in 2001-has been termed the Doha Development Agenda, signifying the intention to focus on development objectives in the world trading system. One of the most important and difficult issues in that agenda is the reform of agricultural policies. Specific reform proposals and objectives are due to the WTO's Committee on Agriculture March 31, 2003, and the topic is to be included in the agenda of the ministerial meeting in Cancun, Mexico, this September.

Agricultural supports take several forms, and the levels of support vary greatly across countries. They are most prevalent, however, among the world's industrialized economies. The Organization for Economic Cooperation and Development estimates that direct and indirect transfers from consumers and taxpayers to farmers in member countries totaled over $\$ 230$ billion in 2001, comprising nearly a third of all farm receipts. Support levels range from a low of 1 percent of farm receipts in New Zealand to a high of 69 percent for Switzerland. Japan, Korea, and Norway are also near the high end of the range, while support levels in Canada, the United States, and the European Union fall somewhere between the two extremes at 17 percent, 21 percent and 35 percent, respectively.

The costs of farm supports are borne primarily by consumers and taxpayers in the industrial countries, as well as by farmers in the developing world. Protectionist agricultural policies in industrial countries tend to keep domestic prices high, so their elimination would enhance consumers' purchasing power. In addition, subsidies tend to increase the total supply of farm products to world markets, driving down international food prices and depressing the incomes of farmers in the developing world. More fundamentally, as with all protective trade policies, agricultural subsidies lead to an inefficient allocation of resources: Countries are induced to specialize in areas that are not necessarily to their comparative advantage.

Officials of major international organizations have emphasized the importance of reducing agricultural supports as part of an overall development agenda. It is often noted that total transfers from consumers and taxpayers to farmers amount to six times the total overseas development aid offered by the industrial countries, and the vast majority of the world's poor are farmers in developing countries whose product prices are depressed by farm-support programs in industrial countries.

Because the costs of farm-support programs are diffuse, the benefits of eliminating these programs would be dispersed widely around the world. A recent International Monetary Fund study calculated the potential gains of eliminating all agricultural support, in both industrial and developing countries: Worldwide, total potential benefits would be $\$ 128$ billion, over 0.4 percent of total world GDP. ${ }^{1}$ The accompanying chart shows that these gains would accrue to residents of every part of the globe.

Reducing the level of trade-distorting agricultural support is a complex issue, and there are powerful interests in maintaining subsidies. However, the magnitude of potential benefits from making the world's agricultural sector more efficient suggests that reducing trade-distorting farm policies is well worth pursuing.

${ }^{1}$ IMF. "How Do Industrial Country Agricultural Policies Affect Developing Countries?” World Economic Outlook, September 2002.

\section{Welfare Effects of Global Agricultural Liberalization}

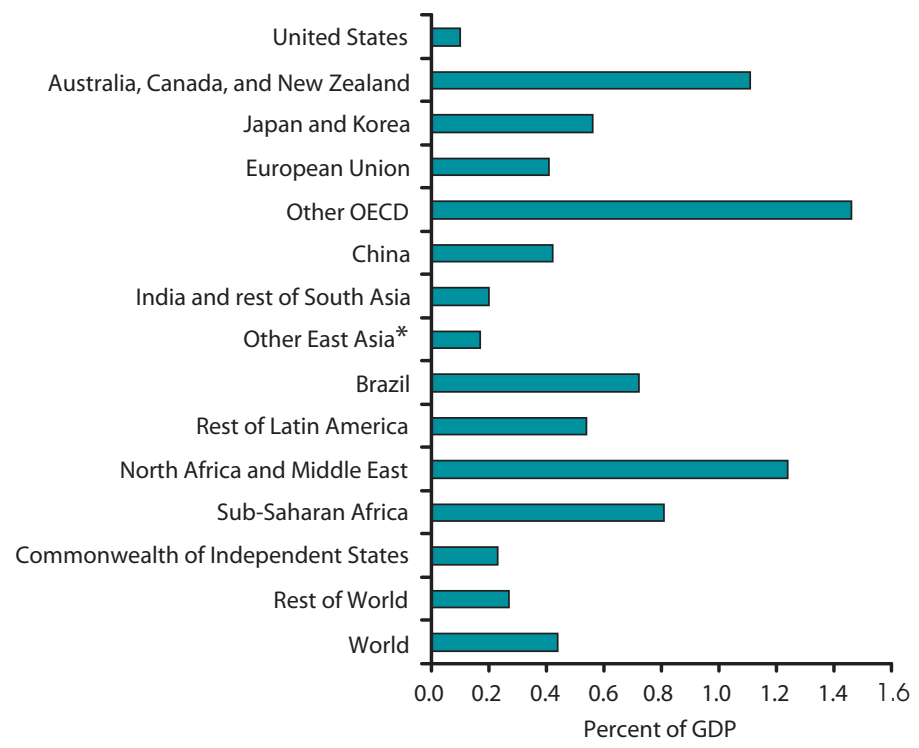

SOURCE: International Monetary Fund.

* Hong Kong, SAR, Taiwan Province of China, Singapore, and other ASEAN. 